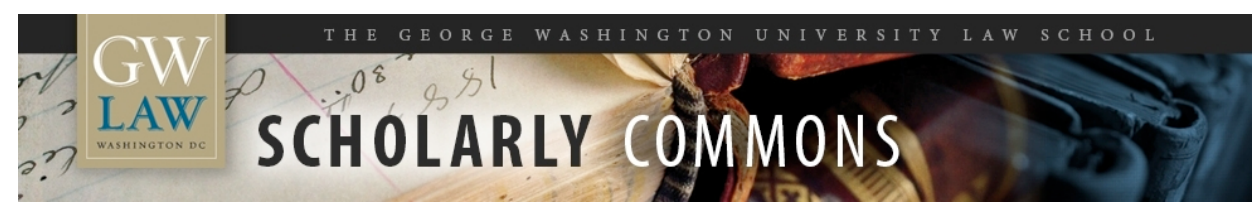

GW Law Faculty Publications \& Other Works

Faculty Scholarship

2007

\title{
Guide to International Environmental Law
}

Dinah L. Shelton

George Washington University Law School, dshelton@law.gwu.edu

Alexandre Kiss

Follow this and additional works at: https://scholarship.law.gwu.edu/faculty_publications

Part of the Law Commons

\section{Recommended Citation}

Dinah L. Shelton \& Alex Kiss, Guide to International Environmental Law in Alexandre Kiss, Dinah Shelton, GUIDE TO INTERNATIONAL ENVIRONMENTAL LAW (Martinus Nijhoff Publishers, 2007).

This Article is brought to you for free and open access by the Faculty Scholarship at Scholarly Commons. It has been accepted for inclusion in GW Law Faculty Publications \& Other Works by an authorized administrator of Scholarly Commons. For more information, please contact spagel@law.gwu.edu. 


\title{
Guide to
}

International

Environmental Law

\author{
Alexandre Kiss \\ and \\ Dinah Shelton
}

Martinus Nijhoff Publishers

Leiden / Boston 


\section{Library of Congress Cataloging-in-Publication Data}

A CIP record of this book is available from the Library of Congress.

ISBN13: 978-1-57105-344-2

Copyright @ 2007 Koninklijke Brill NV, Leiden, The Netherlands.

Koninklijke Brill NV incorporates the imprints Brill, Hotei Publishers, IDC Publishers, Martinus Nijhoff Publishers, and VSP.

All rights reserved. No part of this public may be reproduced, translated, stored in a retrieval system, or transmitted in any form or by any means, electronic, mechanical, photocopying, recording or otherwise, without prior written permission from the publisher.

Authorization to photocopy items for internal or personal use is granted by Brill provided that the appropriate fees are paid directly to the Copyright Clearance Center, 222 Rosewood Drive, Suite 910, Danvers, MA 01923, USA. Fees are subject to change.

Manufactured in the United States of America 


\section{In Memorium Alexandre Kiss}

(June 2, 1925-March 22, 2007)

This publication is the final scholarly work completed by Professor Alexandre Kiss before he passed away in March 2007. The Guide takes its place alongside the several dozen books and more than 400 articles authored by Professor Kiss during his lifetime. As an outgrowth of his doctoral dissertation on abuse of rights in international law, he published his first article on international environmental law in 1967 on the topic of transboundary air pollution. It appeared well before the Stockholm Conference and the emergence of environmental protection as a major international concern. From this ground-breaking article onward, Professor Kiss became an architect of international environmental law, laying its foundations, designing its structure, and participating it its construction. Through nearly half a century he was at the forefront of developing such principles as common heritage of mankind, common concern of humanity, and the rights of future generations. He helped draft some of the foremost legal instruments in the field and participated in elaborating policies and programs for the main international organizations concerned with the environment. His contributions went well beyond his scholarship, however, as he also served as a teacher, mentor, and inspiration to countless students and environmental activists around the world. His joy, dedication, and enthusiasm knew no bounds, nor did his generosity and good will. The hundreds of messages sent in remembrance of him attest to the fact that he was not only respected and revered for his intellectual gifts, he was deservedly beloved for his warmth, good humor, and concern for all components of Creation. 


\section{Table of Contents}

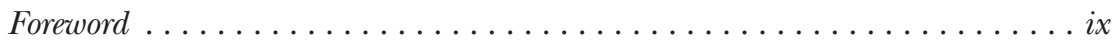

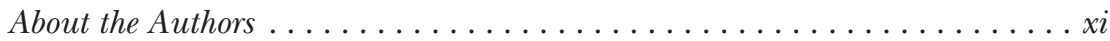

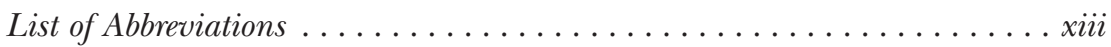

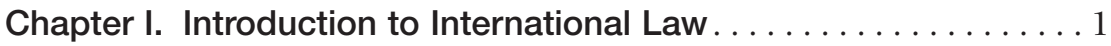

A. The Foundations of International Law . . . . . . . . . . . . 1

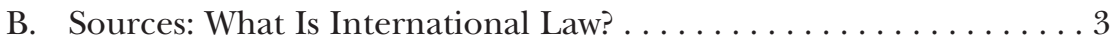

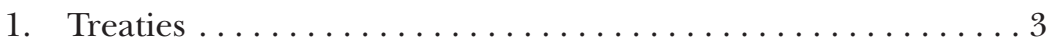

2. Customary International Law $\ldots \ldots \ldots \ldots \ldots \ldots \ldots \ldots$

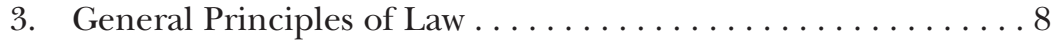

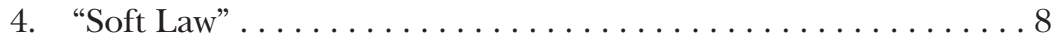

C. Some Basic Principles of International Law . . . . . . . . 11

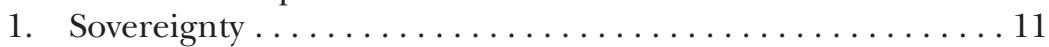

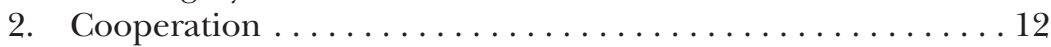

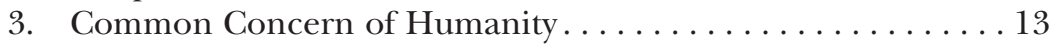

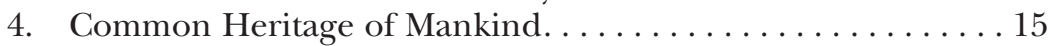

D. The Relationship Between International Law and

Domestic Law ........................... 16

E. Making International Law Work: Compliance and

Enforcement ............................ 18

1. State Responsibility . . . . . . . . . . . . . . . . . 19

2. Strict Liability . . . . . . . . . . . . . . . . 23

Chapter II. The Development of International

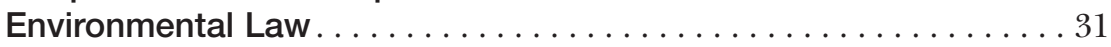

A. The Beginnings to the Stockholm Conference ........... 32

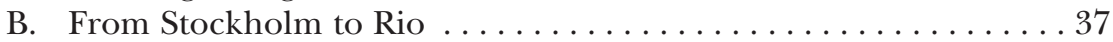

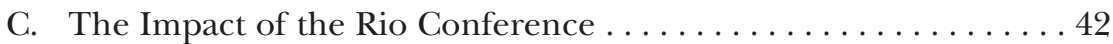

D. The World Conference on Sustainable Development (WSSD) . . . 44 


\section{vi Guide to International Environmental Law}

Chapter III. International Actors and Stakeholders . . . . . . . . 47

A. States and State Authorities . . . . . . . . . . . . . . 47

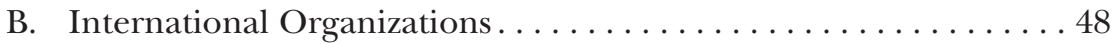

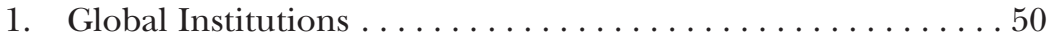

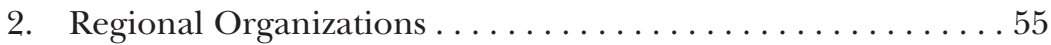

3. Subregional and Bilateral Organizations ............ 62

4. International Financial Institutions $\ldots \ldots \ldots \ldots \ldots \ldots \ldots$

C. The Private Sector. . . . . . . . . . . . . . . . . . . . . . . . 65

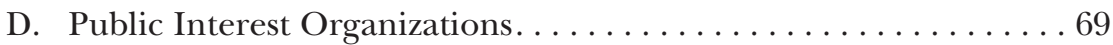

Chapter IV. Multilateral Environmental Agreements. . . . . . . . . 73

A. Negotiations. . . . . . . . . . . . . . . . . . . . . 74

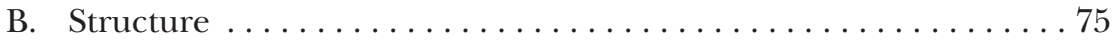

C. Common Provisions and Characteristics of MEAs . . . . . . . . . . 77

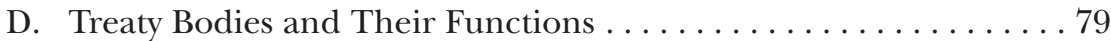

E. Compliance Procedures .................... 81

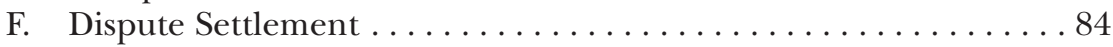

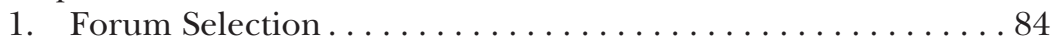

2. Choice of Law. . . . . . . . . . . . . . . . . . . . 86

Chapter V. Common (Customary?) Legal Principles . . . . . . . . . 89

A. Substantive Principles . . . . . . . . . . . . . . . . . . 90

1. Prevention of Harm . . . . . . . . . . . . . . . . . . 90

2. Precaution........................... . 94

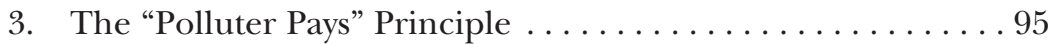

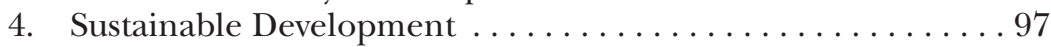

B. Principles of Process . . . . . . . . . . . . . . . . . . . 98

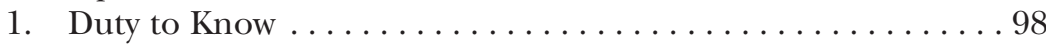

2. Duty to Inform and Consult $\ldots \ldots \ldots \ldots \ldots \ldots \ldots \ldots \ldots$

3. Public Participation ...................... 102

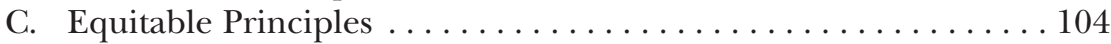

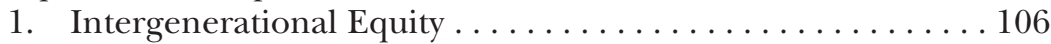

2. Common but Differentiated Responsibilities. . . . . . . . . 107

3. Equitable Utilization of Shared Resources. . . . . . . . . . . 108

D. Conclusions . . . . . . . . . . . . . . . . . . . . . . . . . . . . . 109

Chapter VI. Common Legal Requirements and Implementing Measures ....................... 111

A. Internationally Mandated Domestic Laws and Policies . . . . . . . 112

1. Prior Assessment of Activities . . . . . . . . . . . . . . . . . . . 112
a. EIA ............................ 113
b. Risk Assessment. . . . . . . . . . . . . . . . 117
c. Strategic Environmental Evaluation . . . . . . . . 119 
2. Regulatory Measures . . . . . . . . . . . . . . . . 120

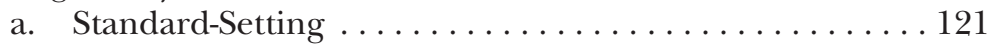

b. Restrictions and Prohibitions . . . . . . . . . . . 123

c. Land Use Regulation . . . . . . . . . . . . . . . . . 125

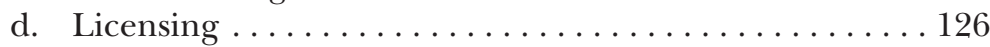

3. Economic Measures ..................... 127

4. National Enforcement .................... 135

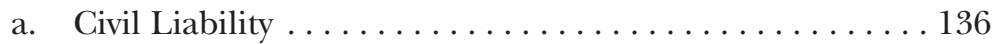

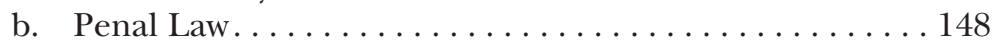

B. Interstate Measures . . . . . . . . . . . . . . . . . . . . . . . . . 149

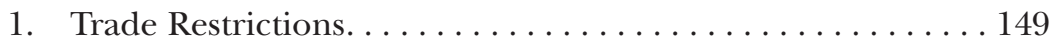

2. Prior Informed Consent Procedures . . . . . . . . . . . 150

3. Aid and Financial Conditionality . . . . . . . . . . 152

Chapter VII. The Substance of International

Environmental Law. . . . . . . . . . . . . . . . . . . . . . 155

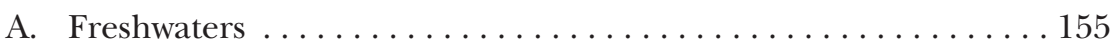

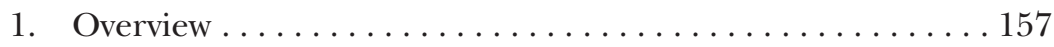

2. General Rules . . . . . . . . . . . . . . . . . . . . . . . 157

B. Atmosphere, Stratosphere, and Climate . . . . . . . . . 160

1. Overview .......................... 161

2. International Efforts to Control Air Pollution. . . . . . . . 162

3. Stratospheric Ozone Depletion and Global Climate Change ......................... 167

a. Ozone Depletion...................... 167

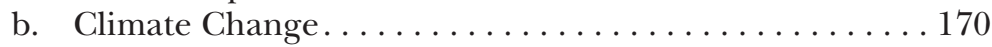

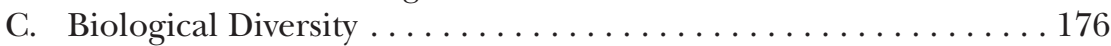

1. The Convention on Biological Diversity............ 178

2. Other Biodiversity Treaties . . . . . . . . . . . . . . . 182

3. Treaties Addressing Specific Threats to Biodiversity . . . . . . 186

4. Agreements Concerning Specific Species . . . . . . . . . . 187

D. Marine Environment. . . . . . . . . . . . . . . . . . . . . . . 190

1. Historical Evolution . . . . . . . . . . . . . . . . . 192

2. UNCLOS: Rights and Duties of States in Maritime Areas. . . 194

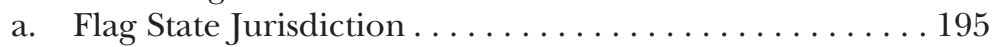

b. Port State Jurisdiction . . . . . . . . . . . . . . . 196

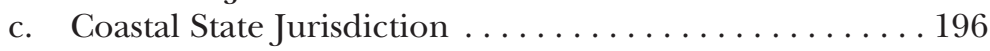

3. Comprehensive Regional Treaties . . . . . . . . . . . 197

4. Regulating Sources of Pollution . . . . . . . . . . . . . 199

a. Vessel Source Pollution. . . . . . . . . . . . . . . 199

b. Exploration and Exploitation of the Seabed. . . . . . . . 201

c. Land-Based Pollution . . . . . . . . . . . . . . . . . . . 202

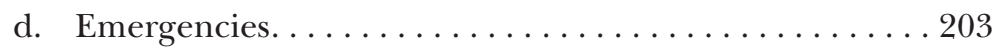

E. Hazardous Substances and Wastes. . . . . . . . . . . . . . 206

1. Chemicals ............................ 207 
viii Guide to International Environmental Law

2. Wastes .............................. 210

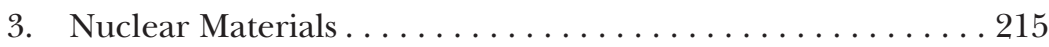

4. Biotechnology......................... 220

Chapter VIII. Environmental Protection in Other Subject

Areas of International Law . . . . . . . . . . . . . . . . . . . . . . . 225

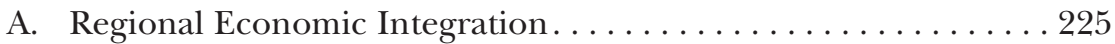

1. The European Union. . . . . . . . . . . . . . . . . 225

a. The Treaty Framework . . . . . . . . . . . . . . 225

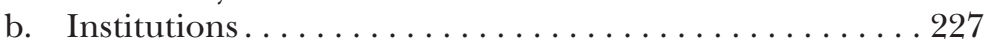

c. Environmental Laws in the EU . . . . . . . . . . . . . 229

i. Air Pollution . . . . . . . . . . . . . . . . . . . . 229

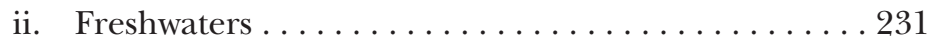

iii. Hazardous Substances and Activities . . . . . . . . . 233

iv. Noise Pollution. . . . . . . . . . . . . . . . . . . . 235

2. Other Regional Economic Integration Efforts . . . . . . . 236

B. Human Rights . . . . . . . . . . . . . . . . . . . 237

C. Trade and Investment. . . . . . . . . . . . . . . . . . . 241

1. GATT/WTO . . . . . . . . . . . . . . . . . . . . . 242

2. NAFTA. . . . . . . . . . . . . . . . . . 250

D. Military Materials and Activities . . . . . . . . . . . . 253

1. Customary and Treaty Law of Armed Conflict. . . . . . . . . 254

2. Claims for Environmental Damages in Armed Conflict . . . . . 260

3. Advisory Opinions and Judgments of the International Court of Justice . . . . . . . . . . . . . . . . . . . . . . . 266

4. Environmental Security and Conflict Prevention ........ 267

Conclusions ............................ 271

Appendix A: Select Bibliography and Internet Sites. . . . . . . . . . 275

Appendix B: Multilateral Environmental Agreements. . . . . . . . . . . . 279

Appendix C: Glossary ............................. 291

Index ..................................... 303 


\section{Foreword}

Since the middle of the 20th century, environmental protection has become a major concern throughout the world. Air pollution, lack of safe drinking water, trade in and disposal of hazardous products and wastes, soil erosion, global climate change, and loss of biodiversity have generated widespread demands for preventive and remedial action to ensure that natural conditions remain conducive to life and to human well-being. Policymakers responding to these demands have increasingly recognized that environmental protection must be addressed in a holistic and expansive manner. Local problems cannot be separated from national, regional, or even global conditions. As a result, the interface of international and domestic (both national and local) environmental law is rapidly expanding.

Such an evolution corresponds to the physical reality of a biosphere composed of interdependent elements that do not recognize political boundaries. These elements are impacted by human activities, which themselves are increasingly transnational. Internationalization of markets and the emergence of a global civil society have presented new opportunities as well as new challenges. Communication networks make possible more rapid knowledge of the existence and scope of environmental problems, but the widespread movement of persons and products may also contribute to those problems, for example, through the introduction of alien species and the spread of pollutants. Over-consumption threatens to exhaust living and non-living resources, while rising greenhouse gas emissions detrimentally modify the global climate. Population concentrations strain resources and create levels of pollution beyond the earth's assimilative capacity. New problems resulting from technology and changes in the nature or scope of human activities are constantly being identified, such as the potential risks of utilizing genetically modified organisms, extending industrial fish- and crustacean-farming, and introducing unprocessed endocrine-disrupting pharmaceuticals into fresh water. As a consequence, there is a constant need to develop and revise the international and national legal framework.

The aim of environmental law is to reduce the anthropogenic sources of environmental harm by modifying human behavior. Environmental law potentially reaches all human activities and falls within the domain of every 


\section{x Guide to International Environmental Law}

governmental institution and level of lawmaking. Other characteristics of environmental law enhance the likelihood of a jurisdictional multiplicity across institutions and venues. First, unlike most international law, environmental regulation addresses the conduct of non-state as well as state actors. Many of the former, at least, are engaged in activities in multiple locales around the world. Second, environmental problems, even more than economic activities, reveal the interdependence of states and peoples. No state, however powerful, can protect its environment without transborder cooperation. Thus, environmental protection inevitably has an international dimension.

This book aims to present the essential elements of international environmental law. It is addressed primarily to environmental lawyers, but it may also be useful for those concerned with international law, environmental policy, and international relations. The book provides a general overview of why and how the international system elaborates environmental obligations and monitors compliance with them. Second, it discusses the relationship between international obligations and national and local law, with particular reference to federal systems. It indicates another interrelationship, pointing out the influence national law has on the emergence of international law as well as the growing role of international norms in the development and enforcement of national and local environmental policies. Finally, it examines the extent to which environmental protection should be and is taken into account in other regulatory frameworks, from trade law and human rights to disarmament and refugee policy. The basic knowledge provided in this book should allow the reader to undertake further research on topics of environmental regulation at the international level and to understand the implications of international environmental law for national law and policy.

The treaties and other texts mentioned are listed and grouped by topic in an appendix. In addition, a bibliography of further readings, a list of Internet sites, and glossary are provided. 


\title{
About the Authors
}

\begin{abstract}
Alexandre Kiss undertook his law studies at the University of Budapest (1943-1947), and at the University of Paris (1949-1951). His Ph.D. dissertation on "L'abus de droit en droit international" was published in Paris in 1952. He studied at the Institut d'études politiques of Paris (diploma in 1949) and the Institut des hautes études internationales de Paris (diploma in 1951). In 1950, after having attended three sessions, he received the diploma of The Hague Academy of International Law. Between 1951 and 1993, Professor Kiss worked at the French National Center for Scientific Research (CNRS), first preparing a Digest of International Law (Répertoire de la pratique française en matière de droit international, 7 volumes, Paris, 1960-1962) then acting as the director of different research centers in Strasbourg and in Paris (1966-1993). Between 1969 and 2002, he participated in the direction of the International Institute of Human Rights (Board member, then Secretary General between 1980 and 1991 and VicePresident between 1991 and 2002). Since 1974, he has been President of the European Council on Environmental Law. He is also board member, vice-president, or president of numerous other NGOs or scientific organizations. He has taught in Strasbourg since 1963 and given lectures, conferences, and participated in scientific meetings in many countries of the world. He has been a consultant for the United Nations Environment Program, UNESCO, UNITAR, the Council of Europe, and the European Union. He was Counsel of the Hungarian government in the GabçikovoNagymaros Project Case submitted to the International Court of Justice (decision of September 25, 1997) and later participated in the negotiations between Hungary and Slovakia as an expert. His publications include 15 books and approximately 400 articles and other texts (book reviews, notes, prefaces) in 14 languages. Professor Kiss has been awarded the Cross of Officer of the French Légion d'Honneur, the Cross of Merit of the Austrian Republic, membership in the Hungarian Academy of Sciences, Doctor Honoris Causa of the University of Leuwen, Elisabeth Haub Prize, and W.E. Burhenne Prize.
\end{abstract}


Dinah Shelton received her B.A. (1967) and J.D. (1970) from the University of California, Berkeley. She also studied at the University of Edinburgh (1965-1966) and the Institut Bourguiba des Langues Vivants, Tunis (1962). She received a post-graduate fellowship from the Ford Foundation and worked at the International Institute of Human Rights in Strasbourg, France from 1970-1973 after which she was an attorney in private practice in San Francisco, California for two years. She began her teaching career in 1975 and has lectured at the University of California, Davis, Santa Clara University, Stanford University, University of California, Berkeley, University of Paris, Strasbourg University, and Notre Dame University. She is currently the Patricia Roberts Harris Research Professor of Law at the George Washington University Law School.

Professor Shelton is the author or co-author of prize-winning books including the Encyclopedia of Genocide and Crimes against Humanity (3 vols., Macmillan Reference, 2004); Remedies in International Human Rights Law (Oxford University Press, 1999, 2d. ed. 2005), which was awarded the Certificate of Merit, by the American Society of International Law in 2000; and Protecting Human Rights in the Americas: Cases and Problems (4th rev. ed. 1996, with T. Buergenthal), winner of the Book Prize, Inter-American Bar Association, 1982. Her most recent publication is R. Lillich, H. Hannum, J. Anaya \& D. Shelton, International Human Rights: Problems of Law, Policy and Practice (Aspen Publishers, 2006).

In the environmental field, she has co-authored or edited numerous works including Judges Manual of International Environmental Law (UNEP, 2005), Economic Globalization and Compliance with International Environmental Agreements (Kluwer, 2003, with A. Kiss and K. Ishibashi), European Environmental Law (Cambridge University Press, 2d ed. 1997. (French edition 1995), and International Environmental Law (Transnational Publishers, 1991, 3d ed. 2004).

Professor Shelton has been a consultant to most international and regional organizations concerned with human rights or environmental protection. She was awarded the 2007 Elisabeth Haub Prize. 


\section{List of Abbreviations}

ALI

Art.

ASEAN

ATCP

ATS

BAP

BAT

BEP

BFSP

CBD

CCAMLR

CDM

CEC

CFCs

CITES

COP

CSD

CTE

CTS

DSU

ECOSOC

EC

ECHR

EEZ

EIA

EMEP
American Law Institute

Article

Association of Southeast Asian Nations

Antarctic Treaty Consultative Parties

Antarctic Treaty System

Best achievable protection

Best available technology

Best environmental practice

British and Foreign State Papers

Convention on Biological Diversity

Commission for the Conservation of Antarctic Marine

Living Resources

Clean development mechanism

Commission on Environmental Cooperation (NAFTA)

Chlorofluorocarbons

Convention on International Trade in Endangered

Species

Conference of the Parties

Commission on Sustainable Development

World Trade Organization Committee on Trade and

Environment

Canadian Treaty Series

Dispute Settlement Understanding

United Nations Economic and Social Council

European Community

European Convention on Human Rights

Exclusive Economic Zone

Environmental Impact Assessment

Cooperative program for the monitoring and evaluation of the long-range transmission of air pollutants 
xiv Guide to International Environmental Law

EMuT

ENMOD

EPL

ETS

EU

EYB

FAO

GATT

GEF

GEMS

IAEA

IBWC

ICAO

ICC

ICJ

ICRC

IFC

ILC

ILM

ILO

IMF

IMO

IPCC

ISA

ISO

ITLOS

IUCN

IWC

JI

Kiss

LMO

LRTAP

MARPOL

MEA

MIGA

MOU

MOP

NAFTA

NATO
Multilateral Environmental Agreements (German

looseleaf service)

Environmental Modification Convention

Environmental Policy and Law

European Treaty Series

European Union

European Yearbook

Food and Agriculture Organization

General Agreement on Tariffs and Trade

Global Environment Facility

Global Environment Monitoring System

International Atomic Energy Agency

International Boundary and Water Commission

International Civil Aviation Organization

International Criminal Court

International Court of Justice

International Committee of the Red Cross

International Finance Corporation

International Law Commission

International Legal Materials

International Labor Organization

International Monetary Fund

International Maritime Organization

Intergovernmental Panel on Climate Change

International Seabed Authority

International Organization for Standardization

International Tribunal on the Law of the Sea

World Conservation Union

International Whaling Commission

Joint implementation

Multilateral Treaties in the Field of the Environment

(UNEP, 1983)

Living modified organism

Convention on Long-Range Transboundary Air

Pollution

International Convention on the Prevention of

Pollution by Ships

Multilateral Environmental Agreement

Multilateral Investment Guarantee Agency

Memorandum of understanding

Meeting of parties

North American Free Trade Agreement

North Atlantic Treaty Organization 
NGO

NPT

OASTS

OJEC

OAS

OAU

OECD

OPIC

OSCE

PCBs

PIC

POPs

PPMs

SALs

SEA

SEE

SPS

TEU

TIAS

TOMAS

UN

UNCC

UNCED

UNCLOS

UNCTAD

UNECE

UNEP

UNESCO

UNFCCC

UNGAOR

UNRIAA

UNTS

UST

VCLT

VOCs

WHO

WMO

WSSD

WTO

WWF
Non-governmental organization

Nuclear Non-Proliferation Treaty

Organization of American States Treaty Series

Official Journal of the European Communities

Organization of American States

Organization of African Unity

Organization of Economic Cooperation and

Development

U.S. Overseas Investment Corporation

Organization for Security and Cooperation in Europe

Polychlorinated biphenyls

Prior informed consent

Persistent organic pollutants

Process and production methods

Structural adjustment loans

Strategic Environmental Assessment

Strategic Environmental Evaluation

Sanitary and Phytosanitary Agreement

Treaty on European Union

U.S. Treaties and Other International Agreements

Tropospheric Ozone Management Areas

United Nations

UN Compensation Commission

United Nations Conference on Environment and

Development

United Nations Convention on the Law of the Sea

United Nations Conference on Trade and Development

United Nations Economic Commission for Europe

United Nations Environment Program

United Nations Educational, Scientific and Cultural

Organization

United Nations Framework Convention on Climate

Change

United Nations General Assembly Official Records

United Nations Reports of International Arbitral Awards

United Nations Treaty Series

United States Treaty Series

Vienna Convention on the Law of Treaties

Volatile organic compounds

World Health Organization

World Meteorological Organization

World Summit on Sustainable Development

World Trade Organization

Worldwide Fund for Nature 


\section{Chapter I \\ Introduction to International Law}

International environmental law is a branch of public international law. While agreements devoted to aspects of environmental protection have developed their own particularities, which are discussed throughout Chapter IV, the structures and norms of international law provide the basic legal framework for the field. Within this framework, international rules having quite varied objectives often need to be included as part of international environmental law, because they have a significant environmental impact. The first fishing treaties, for example, were primarily intended to prevent conflicts between fishermen of different nationalities and to protect local economies. Fulfillment of these objectives nonetheless fostered the concept of sustainable exploitation, permitting the maintenance and renewal of fish stocks. Similarly, norms to standardize the performance of internal combustion engines, originally adopted by the European Union in order to facilitate trade within the region, have led to cleaner technology and reductions in engine noise and the emission of noxious gases. In sum, the field of international environmental law encompasses large parts of public international law as well as being subsumed within its basic structure.

This chapter provides an introduction to the basic elements of the international legal system: whom it governs, how it is made, and how it relates to the internal laws of states. The final section addresses issues of compliance and enforcement, with further attention devoted to this topic in Chapter IV, Sections E and F..

\section{A. THE FOUNDATIONS OF INTERNATIONAL LAW}

International law was long defined as the body of binding norms governing the relations between states. If states create international law, the reverse is also true, to some extent, because international law establishes 


\section{Guide to International Environmental Law}

the requisite characteristics of a state. International law also confers upon states unique rights and privileges denied other types of institutions and organizations. International law thus can be seen as acknowledging the reality that over millennia humankind has divided itself into almost 200 independent political and legal units, each having its own territory, population, economy, and government. The fundamental rights recognized for states are, first, legal independence from other states and, second, exclusive jurisdiction over activities within their own territory. These rights are often referred to as external sovereignty and internal sovereignty. It is primarily the lack of external sovereignty that distinguishes the component parts of federal unions from states recognized as part of the international system.

The sovereignty of states has a determinative impact on the law-making process, by implying that state consent is needed both to create international legal obligations and to invoke procedures for the settlement of international disputes. The UN Charter today has near universal acceptance and proclaims fundamental rules for the global society, but the organization has no legislative power. Other international organizations also lack law-making capacity. Thus, while international law aims to secure the cooperation of states to address common problems, from maintaining peace to protecting the environment, the resolution of such problems depends upon states recognizing the need to draft and voluntarily accept appropriate legal obligations, either by concluding treaties or by engaging in common practices that lead to the emergence of customary international rules.

The scope and content of international law is vastly greater today than it ever has been. Modern authorities agree that international law is not limited to regulating states, but it may also govern international organizations, other legal persons, and even individuals. In the Third Restatement of the Foreign Relations Law of the United States, international law is defined as the law that concerns "the conduct of states and of international organizations and with their relations inter se, as well as with some of their relations with persons, whether natural or juridical." ALI, Restatement of the Foreign Relations law of the United States (Third), $§ 101$ (1987). International law may create rights and obligations governing these persons and establishes procedures and institutions to monitor compliance with international norms. The modern definition is particularly important in the field of environmental protection, because most environmental harm is caused by private sector activities and not those of governments. The ability of international law to regulate non-state conduct is thus essential to achieving effective environmental protection.

While international law may regulate some of the actions of non-state actors, that law remains a product of express or implicit agreement among states. Non-state actors may and certainly do contribute to the elaboration of international texts and influence state behavior in ways that may contribute to the development of international custom, but they do not as 
such make public international law. Instead, as discussed in the next section, international law regulates conduct through rules based on the consensual adoption of treaties and the development of customary international law based on state practice viewed as obligatory (opinio juris). Those rules normally become binding on non-state actors through their incorporation into the domestic law of states. Only rarely, and largely in the field of crimes, does international law impose direct obligations on purely private conduct.

\section{B. SOURCES: WHAT IS INTERNATIONAL LAW?}

International law is created and identified in reliance on law-making "sources" set forth in Art. 38(1) of the Statute of the International Court of Justice (ICJ), initially drafted in 1920 for its predecessor, the Permanent Court of International Justice. Although applying only to the ICJ, Art. 38 represents the authoritative listing of processes that states have identified and accepted as capable of creating rules binding on them; it remains, to date, the only such listing. It sets out, in order, general or specialized international conventions (treaties), international custom as evidence of a general practice accepted as law, and general principles of law recognized by civilized nations. Judicial decisions and doctrine are cited in Art. 38 as "subsidiary means to identify" or find international law, but neither constitutes a means by which law is directly created.

Art. 38 does not explicitly set a hierarchy among the three law-making sources, and the relationships can be complex. In general, treaties are interpreted in conformity with customary law where possible, but it is accepted that states inter se can modify their customary international obligations by treaty, provided the customary obligations do not constitute peremptory or fundamental norms of international law. In such an instance, the treaty provisions would be considered against international public policy and invalid. See Art. 53, Vienna Convention on the Law of Treaties (VCLT) (May 23, 1969), 1155 UNTS 331.

Current international practice also relies heavily on the diverse activities of international organizations, which can contribute to the development of a new rule of law, in particular, by adopting non-binding texts, in which member states may express approval for the emergence of new norms. Such texts play more than a nominal role in the formation of international law in general and environmental law in particular. These nonbinding normative instruments are discussed below under the heading by which they are commonly known: "soft law."

\section{Treaties}

Most legal obligations today derive from treaties. The VCLT defines a "treaty" as "an international agreement concluded between States in written form and governed by international law, whether embodied in a sin- 


\section{Guide to International Environmental Law}

gle instrument or in two or more related instruments and whatever its particular designation." VCLT, Art. 2.1(a). This definition omits all international agreements to which intergovernmental or non-governmental organizations are parties as well as agreements concluded by internal agencies not entitled to bind the state, for example port authorities or customs offices. Yet, all these entities enter into agreements intending to cooperate and apply agreed norms for environmental protection. In fact, a separate Vienna Convention, concluded in 1985, concerns treaties entered into by international organizations. It also should be noted that while the VCLT definition of treaties refers to agreements in writing, the Permanent Court of International Justice held that oral agreements may be legally binding. Case concerning the Legal Status of Eastern Greenland (Den. v. Nor.), 1933 P.C.I.J. (ser. A/B) No. 53. Most importantly, the definition indicates that the question of whether or not a given text is a treaty is determined by whether or not it is governed by international law, i.e., is legally binding. This is a matter of the intent of the states concluding the agreement and concededly produces the somewhat circular notion that an instrument is a treaty if it is legally binding, and it is legally binding if it is a treaty. From state practice, however, it is clear that many international agreements are not intended to be legally binding, but to express political commitments. Failure to abide by such non-binding agreements may be considered unfriendly or a political affront, but the failure does not constitute a breach of international law.

Practice in the United States accepts the conclusion of executive agreements by the President acting within his foreign affairs powers. While these are not considered treaties for the purpose of Senate advice and consent to ratification, many of them are negotiated as legally binding treaties under international law. They may be given effect in domestic law as well, but it is not entirely clear that they constitute treaties for purposes of the Supremacy Clause (Art. VI) in all instances. In Dames and Moore v. Regan, 453 U.S. 654 (1981), the U.S. Supreme Court upheld and gave effect to the Algiers Accords, a presidential agreement with Iran that terminated claims of U.S. nationals against the Iranian government in exchange for the release of U.S. hostages being held in Teheran. The Court concluded that the agreement was a valid presidential action overriding existing claims in state and federal courts. Other executive agreements settling claims have been given similar preemptive effect. See, e.g., Am. Ins. Ass'n v. Garamendi, 539 U.S. 396 (2003), holding that "[g]enerally, . . . valid executive agreements are fit to preempt state law, just as treaties are." The question of executive agreements involving matters other than settlement of claims or recognition of foreign governments remains open.

Until the 20th century, treaties were nearly all bilateral and mostly concerned boundaries, diplomatic relations, the high seas, shared freshwaters, trade, and extradition. The governing principle was reciprocity of obligations. The principle of reciprocity established a legal equilibrium between 
the obligations accepted by one state and the advantages it obtained from the other contracting party.

Exceptions to reciprocal treaties have long existed and include bilateral and multilateral treaties to combat slavery and the slave trade, abolition of child labor and other humanitarian topics. Typically, these agreements confer benefits on individuals and not on other states parties; for this reason they are often referred to as creating unilateral obligations. Following World War II, non-reciprocal obligations enlarged still further to include the general international protection of human rights, regulations on the use of Antarctica and its surrounding seas, codes governing activities in outer space, and reaffirmation of freedom of the high seas with an obligation to safeguard the marine environment. Rules of international environmental law may be considered among the non-reciprocal obligations, as generally they do not bring immediate reciprocal advantages to contracting states when their objective is to protect species of wild plant and animal life, the oceans, the air, the soil, and the countryside. Sovereign equality is also implicated, because, e.g., states upstream on an international river are not in the same situation as those downstream. For coastal states, similarly, the general direction of winds and ocean currents may cut against the equality of the parties and diminish reciprocity in legal benefits and burdens.

Today, multilateral regulatory treaties are common, the topics governed by international law have proliferated, and non-state actors are increasingly part of the international legal system. Modern treaties often affect a state's internal laws and practices rather than directly regulating interstate relations, as was the case with earlier bilateral agreements. Describing these developments, some international jurists have posited the existence in international law of "treaty-laws," distinguished from "treaty-contracts." In its Advisory Opinion on Reservations to the Convention on Genocide, 1951 ICJ 15, the International Court of Justice provided support for this idea by distinguishing reciprocal treaties from conventions like the Genocide Convention in which states do not have any interests of their own; instead, "they merely have, one and all, a common interest, namely, the accomplishment of those high purposes which are the raison d'être of the convention." In a subsequent case, the Court said that agreements like the Genocide Convention created obligations erga omnes, duties owed to all states. If this is the case, it may imply that any and all states have standing to complain of violations by one of the parties, since no state is likely to suffer material injury, but all suffer legal injury due to the violation of law. In municipal law, a similar distinction is made between public law legislated in the general interest and contract law that allows parties to create private rights and duties by contract.

Treaties are normally negotiated by authorized representatives of the heads of state during negotiations that are held within an international organization or at a diplomatic conference called for the purpose. A treaty 


\section{Guide to International Environmental Law}

text may be adopted by vote or by consensus and then opened for signature. Signature can serve several purposes. With bilateral agreements, but only rarely with multilateral agreements, it may express the consent of the state to be legally bound to the treaty. VCLT, Art. 12. More commonly, signature acts as an authentication of the text and a statement of intent to submit the treaty to the appropriate national body for ratification, i.e., formal approval by the highest authorities of the state. Once a state has signed a treaty, pending ratification, the VCLT provides that the state is obliged to refrain from acts that would defeat the object and purpose of the treaty until it makes clear its intention not to become a party. VCLT, Art. 18. Most treaties today are concluded in several "authentic" languages, which are presumed to have the same meaning. VCLT, Art. 33. UN practice makes treaties authentic in the six official languages of the organization (English, French, Spanish, Arabic, Russian and Chinese).

Once the text has been approved by the negotiating body, most agreements specify the means by which states signal their acceptance, and this is usually by ratification of it. If ratification is required, the domestic approval of the treaty must be followed by deposit of an instrument of ratification with the authority designated as the "depository," to inform other parties to the treaty that it has been accepted. A state that has not signed the treaty and wishes to join will usually file an instrument of accession rather than ratification; there is no legal significance to the different terminology. Multilateral treaties usually specify a minimum number of ratifying states for the treaty to enter into force and become legally binding on the states parties as of that date.

In order to maximize state participation in multilateral agreements, provisions may be included allowing reservations to be entered at the time of signing, ratification, or accession. A reservation is a unilateral statement by a state that excludes or modifies the legal effect of one or more provisions of the treaty as applied by that state. VCLT, Art. 1(b). States sometimes call statements reservations when they are not, because they do not affect the legal obligations, and sometimes states will label as an "understanding" a statement that is in fact a reservation. The test is whether or not the rights or duties under the treaty are modified in any way. Many modern environmental agreements bar reservations because of the complicated package of bargains made during the negotiations. See UNCLOS, Art. 309 (Dec. 10, 1982); Convention for the Protection of the Ozone Layer, Art. 18 (Vienna, Mar. 22, 1985); Protocol on Substances that Deplete the Ozone Layer, Art. 18 (Montreal, Sept. 16, 1987), CBD, Art. 37 (Rio de Janeiro, June 5, 1992); and Protocol on Biosafety, Art. 38 (Montreal, Jan. 29,2000 ). If a treaty does not contain a provision on reservations, general international law permits a state to make reservations so long as they are compatible with the object and purpose of the treaty. VCLT, Art. 19.

For treaties in force, the fundamental rule of treaty law is "pacta sunt servanda"- treaties that a state has accepted must be performed in good 
faith. Neither the rupture of diplomatic relations nor a change of government affects the continuity of treaty obligations. As with contract law, there are nonetheless rules that govern the validity of treaties and provide legitimate excuses for non-performance by a party, including such matters as duress, impossibility of performance, fundamental change of circumstances, or material breach by another party. Armed conflict may affect the continuity of some agreements, but not those aimed at the protection of the human person or the environment.

In general, treaties are not retroactive and only apply from the moment they enter into force for a particular state. Some treaties may allow denunciation after a specified notice period, but many others are of indefinite duration. Unless otherwise stated, treaties apply to all persons and territories over which the state has jurisdiction, including aircraft, ships, and space objects. Complex issues of jurisdiction may arise where sovereignty is divided due to occupation or where sovereignty is absent, as in Antarctica.

The interpretation of a treaty is governed primarily by its text. VCLT Art. 31 is accepted as a statement of customary international law on the topic. It provides that words of a treaty are to be interpreted in good faith in accordance with their ordinary meaning in context, in light of the object and purpose of the treaty. VCLT, Art. 31. Other rules of international law and the subsequent practice of the states parties to the agreement are taken into account in establishing the parties' understanding of the meaning of terms and the object and purpose of the treaty. These have proven more important in multilateral treaty interpretation than the original intent of the drafters, which the VCLT relegates to a subsidiary role, to confirm meaning or resolve ambiguities arising through application of the primary rules of interpretation. The emphasis on the text and subsequent practice is particularly useful in giving effect to multilateral agreements, where the original intent of nearly 200 states would be extremely difficult to ascertain independently of the agreed-upon text. The intent of the parties can be more readily determined for bilateral treaties, where the drafting history found in the minutes and other documentation is less complex and contradictory.

The failure to observe a treaty is an international wrong, giving rise to state responsibility to cease the breach and make reparations for any injuries caused to another state. Domestic law, whether constitutional, statutory or case law, is no defense to failure to perform treaty obligations. Treaty enforcement traditionally was done by the injured party, which could withhold benefits under the treaty, applying the principle of reciprocity. Thus, the failure of one state to comply with the requirements of a bilateral extradition treaty could result in its treaty partner refusing to extradite in response. Trade agreements remain an area where the threat of retaliatory action is a means of deterring violations and enforcing the treaties. Where consequential harm occurs that cannot be cured by reci- 


\section{Guide to International Environmental Law}

procal action, an injured state may assert a claim for reparations under the law of state responsibility, usually through diplomatic channels, but increasingly in international tribunals.

Since the creation of the United Nations, multilateral treaties rely less on retaliatory action in the case of breach and more on the creation of institutions and compliance mechanisms to review state compliance. Such procedures may result in publication of reports that identify failures, adoption of incentives, or other actions aimed at promoting compliance.

\section{Customary International Law}

The content of customary international law is found in widespread and consistent state practices, followed because the states believe the practices are legally required. State practice must be general, although it need not be universal. State practice is identified through, e.g., official government texts and statements, court decisions, laws, and diplomatic exchanges. See Filartiga v. Pena-Irala, 630 F.2d 876 (2d Cir. 1980). Conduct in violation of such official acts is treated as a violation of the law, not as extinguishing the custom. If a significant number of states adopt laws and official policies that lead them to act contrary to the purported rule, a new norm may emerge.

Not all state practice forms customary international law. State acts engaged in because they are convenient or polite do not give rise to custom, because the sense of legal obligation is absent. Instead, states must have a conviction that the rule is obligatory, referred to as opinio juris. Such opinio juris may be implied if state practice is general and consistent over a lengthy time.

\section{General Principles of Law}

General principles of law are those concepts and rules found in the major legal systems of the world and appropriate for application in international relations. Since such rules have been adopted in national law, consent to their application in international law is inferred. Thus, the International Court of Justice recognized the existence of corporations as legal persons in the Barcelona Traction case based on wide recognition of the personality of such business entities in modern law. Barcelona Traction, Light and Power Company, Ltd. (Belg. v. Spain) 1970 ICJ 3 (Feb. 5). General principles have often been used to fill in gaps in international law during interstate litigation.

\section{4. "Soft Law"}

States now often place normative statements and agreements in non-legally binding or political instruments, such as declarations, resolutions, and programs of action. These instruments, often referred to as "soft law" may 
make it easier to press dissenters into conforming behavior, because states are free to use political pressure to induce others to alter their policies, although generally they cannot demand that others conform to legal norms the latter have not accepted. Non-binding commitments may be entered into precisely to reflect the will of the international community to resolve a pressing global problem over the objections of one or a few states causing the problem, while avoiding the doctrinal barrier of their lack of consent to be bound by the norm. New problems also may require innovative means of rulemaking when non-state actors are the source of the harm and target of the regulations; they generally cannot negotiate or be parties to treaties, and they are not involved in the creation of customary international law, but they have a direct interest in any legal regulation adopted. Their participation may thus be crucial to effectiveness of the law. The emergence of codes of conduct and other "soft law" in part reflects the desire to bring them into the law-making process.

Several other reasons may be adduced for the increasing use of nonlegally binding instruments:

1. The statutes of most international intergovernmental organizations do not invest organs of the institution with the right to adopt binding decisions, so that they can express their will-or rather the will of their member states on specific matters-only through recommendations or other declarative acts. The recommendations may contain normative statements, but they are not binding. International conferences of states, like the Stockholm Conference on the Human Environment, often similarly result in declarations that express the conclusions of the meeting and agreed principles for future action, including statements of law. Some recommendations, such as the resolutions of the UN General Assembly concerning the prohibition of large-scale pelagic driftnet fishing, or the recommendations of the Organization for Economic Cooperation and Development concerning transboundary pollution, can became binding rules at the end of an evolution of state practice (customary law) or by repetition and incorporation in binding national and international legal instruments.

2. Multilateral conventions relating to environmental protection have created specific organs such as the Conferences of Parties, assisted by secretariats and, in some cases, by specialized bodies. The power of such organs to adopt decisions and norms that are binding for the states parties varies and is often uncertain. Legal counsels may issue opinions that have an impact but are not legally binding.

3. Non-binding texts are typically easier than treaties to negotiate quickly and amend in the light of new problems. Scientific knowledge and public awareness can be the major factors pressing for international action. 


\section{Guide to International Environmental Law}

4. States may decide to forego the often lengthy treaty-making process to avoid domestic constitutional or political barriers. Recommendations, joint declarations, guidelines, or other common rules of conduct express their commitments, but do not necessitate formal ratification. Texts that are not subject to national ratification can take instant effect. This is the case, for instance, with the safety regulations drafted by the International Atomic Energy Agency

5. In some circumstances, the subject matter under consideration may make non-legally binding instruments more appropriate than formal agreements. The best examples are Action Plans, such as Agenda 21, adopted by the 1972 Rio Conference on Environment and Development, and the Arctic Environmental Protection Strategy. The contents set out general policy goals and guiding principles, rather than specific legal obligations capable of immediate implementation.

6. The drafting and implementation of soft law instruments more easily allows the participation of international institutions and non-state actors than does the process of treaty negotiating, which is usually formal and restricted to delegates from states. IUCN prepared the first draft of the World Charter of Nature, which was sent out by the UN General Assembly to the member states for comments, after which the Assembly adopted it on October 28, 1982. NGOs also can participate in the adoption and the monitoring of special agreements that are formally not binding, such as Memoranda of Understanding (MOUs). The Convention on the Conservation of Migratory Species of Wild Animals (Bonn, Sept. 19, 1979), for example, was complemented by several MOUs or administrative arrangements signed not only by states but also by so-called "co-operating organizations" including intergovernmental and non-governmental bodies.

7. Some non-governmental industrial, environmental, and consumer protection associations adopt norms that can be implemented as legal rules. The International Organization for Standardization (ISO), a non-governmental body founded in 1946 to promote voluntary international standards and to facilitate global trade, has adopted a number of worldwide technical standards related to the environment. The ISO is composed of over 100 national standardization bodies, one from each represented country. Although ISO is an NGO, most national bodies participating in it are public agencies, giving it a mixed character.

In sum, non-binding rules have the necessary flexibility to enable the international community to approach problems requiring international cooperation, such as the protection of migratory species, or to address new matters, like promoting sustainable energy sources. Parallel to this evolution, it may be noted that national authorities also make use of non-binding or voluntary agreements with private parties, such as industrial associations, forest or other landowners, indigenous groups, or scientific 
institutions. These non-binding instruments can involve scientific research, land use, or reduction of pollution.

While non-binding international agreements sometimes are criticized as ineffective, compliance with such instruments may reach high rates. Different factors affect compliance with non-binding norms, just as they affect compliance with binding ones. Compliance may be enhanced by the presence of a legally binding text that provides the legal foundation for the non-binding instrument. The content or substance of the non-binding norm can assist compliance if it is sufficiently precise to allow for immediate implementation and enable the appropriate bodies to monitor compliance and to take sanctions against those who do not respect it. The involvement of regional and local authorities in compliance procedures also can be a positive factor. National authorities may foster awareness of such norms through media coverage, at all levels, involving regional and local authorities as well as civil society.

\section{SOME BASIC PRINCIPLES OF INTERNATIONAL LAW}

International law rests on several foundational principles, some of which have particular importance for the development of international environmental law. The UN Charter in Article 2 sets forth those principles deemed to be of constitutional importance to the United Nations and its member states: sovereign equality; good faith compliance with agreements to which a state is a party; cooperation in addressing matters of international concern; non-interference in the domestic affairs of states; and peaceful settlement of international disputes. Key to all of these principles is the concept of state sovereignty.

\section{Sovereignty}

State sovereignty, one of the oldest principles of international law, means that each state has exclusive legislative, judicial, and executive jurisdiction over activities on its territory. Sovereignty is exercised subject to international law, however, and is not absolute. States may enact or accept limits on their own freedom of action in order to protect common interests or the interests of other states.

Treaties to which a state becomes a contracting party result in selfimposed limits on sovereignty. In recent decades, states have concluded a large number of environmental treaties containing obligations that must be executed on their territories, including agreements to protect species of wild fauna and flora, prohibit the dumping of harmful substances into rivers, lakes or the sea, and prevent atmospheric pollution. As a consequence, states are obliged to exercise broad control over public and private activities, and this necessarily places legal limits their freedom of action. 


\section{Guide to International Environmental Law}

The sovereign rights of states include exclusive jurisdiction over their resources. Principle 21 of the Stockholm Declaration, adopted in 1972, explicitly applies this principle to environmental matters by affirming that "[s] tates have, in accordance with the Charter of the United Nations and the principles of international law, the sovereign right to exploit their own resources pursuant to their own environmental policies." On the Stockholm Conference and Declaration, see Chapter II, Section A. Two decades later, the Rio Declaration modified this language by referring to "environmental and developmental policies." See Chapter II, Section B. It is thus up to each state, subject to its treaty and customary obligations, to determine the level of environmental protection it aims to achieve.

Exploitation of a state's resources has the potential to infringe the sovereignty of other states due to transfrontier environmental impacts; in addition, many species of wild animals, birds, and fish migrate across boundaries, threatening to create interstate disputes over rights to them. Avoiding conflict and managing these resources requires international law. Hence, the Stockholm Declaration and other international texts balance state sovereignty with "the responsibility to ensure that activities within their jurisdiction or control do not cause damage to the environment of other States or of areas beyond the limits of national jurisdiction." The duty to prevent extra-territorial environmental harm and the corresponding law of state responsibility are further discussed at Section E.

\section{Cooperation}

An obligation to cooperate with other states emerges from the very rationale for international law and finds reflection in the proliferation of international agreements and institutions. In the field of environmental protection, equitable use of shared resources, such as transboundary watercourses and international lakes, especially depends upon international cooperation. The general need to cooperate to conserve the environment is expressed in several non-binding texts, starting with Principle 24 of the Stockholm Declaration. Several UN General Assembly resolutions, the 1982 World Charter for Nature, and the Rio Declaration on Environment and Development also refer to it.

The principle of cooperation underlies all treaty obligations, but several texts specify the aims of state cooperation. Article 197 of the 1982 Convention on the Law of the Sea is an example:

States shall cooperate on a global basis and, as appropriate, on a regional basis, directly or through competent international organizations, in formulating and elaborating international rules, standards and recommended practices and procedures consistent with this Convention, for the protection and preservation of the marine environment, taking into account characteristic regional features. 
Similarly, Principle 5 of the Rio Declaration calls for cooperation to eradicate poverty. Principle 27 adds that cooperation shall be conducted in good faith and shall include further development of international law in the field of sustainable development. Specific duties of cooperation apply to the transnational transfer of activities and substances that cause severe environmental degradation or are harmful to human health. See Rio Declaration, Principle 14, and the Convention on the Control of Transboundary Movements of Hazardous Wastes and their Disposal (Basel, Mar. 22, 1989).

Environmental treaties and other texts frequently call for cooperation in the transfer of funds, knowledge, information, and technology, to assist developing countries to comply with their treaty obligations or more generally to achieve sustainable development. See 1992 UN Framework Convention on Climate Change, Art. 4(5); Convention on Biological Diversity, Art. 20(2); Convention to Combat Desertification in those Countries Experiencing Serious Drought and/or Desertification, Particularly in Africa, Arts. 20 and 21 (June 17, 1994).

An order on provisional measures issued December 3, 2001, by the International Tribunal on the Law of the Sea in the Mox Case (Ireland $v$. U.K.) indicates that the duty to cooperate may be legally enforceable. Ireland invoked UNCLOS Art. 123, which requires states to cooperate in exercising their rights and performing their duties with regard to enclosed or semi-enclosed seas, in this case the Irish Sea. Ireland also relied upon UNCLOS Article 206, which requires prior assessment of planned activities that may cause substantial pollution or significant and harmful changes to the environment. The Court, in paragraph 82 of its order, concluded that UNCLOS and general international law make the duty to cooperate a fundamental principle for the prevention of marine pollution and that rights arise therefrom, which the tribunal may preserve through ordering provisional measures. Mox Plant Case (Ire. v. U.K.), ITLOS, Dec. 3, 2001, 41 ILM 405 (2002).

\section{Common Concern of Humanity}

The cohesion of every society is based upon and maintained by a value system. The system may demand respect for the human person, propriety, patriotism, cultural values, or a particular social order. The protection of such fundamental values is generally recognized as a common concern of the community and is ensured through law, especially constitutional law.

During the second half of the 20th century states created an international political organization to maintain international peace and security and improve human well-being. This ambitious effort led to identifying defining domains of common concern. The international recognition of human rights and fundamental freedoms was a first step in developing the concept of an international community built upon the fundamental val- 


\section{Guide to International Environmental Law}

ues of humanity. Similarly if somewhat later, protection of the human environment became accepted as a common concern of humanity. The ecological processes of the biosphere, such as climate change, necessitate protection at the global level, while transboundary and many domestic environmental issues cannot be managed effectively by national efforts alone. The modalities of protection and preservation are formulated in international law and policy and enforced by national and international institutions.

The term "common interest" appeared early in international treaties concerning the exploitation of natural resources. The preamble to the International Convention for the Regulation of Whaling (Washington, Dec. $2,1946)$ recognizes the "interest of the world in safeguarding for future generations the great natural resources represented by the whale stocks" adding that "it is in the common interest" to achieve the optimum level of whale stocks as rapidly as possible. The Convention for the High Seas Fisheries of the North Pacific Ocean (Tokyo, May 9, 1952) expresses the conviction of the parties that it will best serve the common interest of mankind, as well as the interests of the contracting parties, to ensure the maximum sustained productivity of the fishery resources of the North Pacific Ocean. Other examples include the Convention on Biological Diversity (1992) ("affirming that the conservation of biological diversity is a common concern of humankind") and the UN Framework Convention on Climate Change ("change in the Earth's climate and its adverse effects are a common concern of humankind").

The international concept of common concern does not connote specific rules and obligations, but establishes the general legal basis for the concerned community to act. Designating a matter as one of common concern removes the topic from states' exclusive domestic jurisdiction and makes it a legitimate matter for international regulation. The conventions cited above thus imply a global responsibility to conserve disappearing or diminishing wild fauna and flora, ecosystems, and natural resources in danger.

The right and duty of the international community to act in matters of common concern still must be balanced with respect for sovereignty. States retain exclusive jurisdiction subject to the obligations international law creates to assure the common interest.

Respect for human rights, economic development, and environmental protection have been unified in the concept of sustainable development as a common concern of humanity. Other domains of international law, such as international trade, are instrumental in achieving the common interest but they are not themselves among the ultimate goals of international society. Instead, they are means to achieve the well-being of humanity as a whole. The terms of the UN Charter indicate that international peace and security, together with economic and social advancement of all peoples and individuals, are also necessary to ensure the overall advancement of humanity. 
The notion of common interests shared by the international community may have procedural implications. In traditional international law, only an injured state could bring a claim against the state which caused the injury in violation of international law. Where the common interest is infringed, however, all states may be considered to have suffered a legal injury, with the obligations designated as obligations owing to all states, i.e., as obligations erga omnes. In the Barcelona Traction, Light and Power Company, Limited Case (Belg. v. Spain, Second Phase) 1970 ICJ 4, 32, the International Court of Justice recognized the distinction between different kinds of norms:

[A]n essential distinction should be drawn between the obligations of a State towards the international community as a whole, and those arising vis-a-vis another State in the field of diplomatic protection. By their very nature the former are the concern of all States. In view of the importance of the rights involved, all States can be held to have a legal interest in their protection; they are obligations erga omnes.

The Court included, in the category of obligations erga omnes, the international laws prohibiting aggression, genocide, slavery and racial discrimination. More recently, the International Court of Justice has cited with approval the view of the International Law Commission that safeguarding the earth's ecological balance has come to be considered an essential interest of all states, as it aims to protect the international community as a whole. See Case Concerning the Gabçikovo-Nagymaros Project (Hung. v. Slovakia), 1997 ICJ 7, para. 53 (Sept. 25), citing the International Law Commission, Commentary to Art. 33 of the Draft Articles on the International Responsibility of States, [1980] 2 (Part 2) Y.B. Int'l L. Comm'n 39, para. 14. Thus, some of the codified norms and customary standards in the environmental field may be viewed as obligations erga omnes.

\section{Common Heritage of Mankind}

The common heritage of mankind is a controversial concept that emerged at the end of the 1960s to challenge older concepts of res nullius and res communis as a legal approach to regulating the use of common resources. Res nullius, which in many legal systems includes wild animals and plants, belongs to no one and can be freely used and appropriated when taken or captured. The designation of res communis implies the reverse, common ownership that precludes individual appropriation but allows use of the resources, e.g., navigation on the high seas. The concept of common heritage of mankind is distinct from both earlier concepts, in part because of its inclusion of the word "heritage," connoting a temporal aspect in the communal safeguarding of areas legally incapable of national appropriation. In part based on this concept, special legal regimes have been cre- 


\section{Guide to International Environmental Law}

ated for the deep seabed and its subsoil, Antarctica, and the Moon.

The nature of the common heritage is a form of trust whose principal aims are exclusive use for peaceful purposes, rational utilization in a spirit of conservation, good management or wise use, and transmission to future generations. Benefits of the common heritage may be shared in the present through equitable allocation of revenue, but this is not the essential feature of the concept. Benefit-sharing can also mean sharing scientific knowledge acquired in common heritage areas, and is applied to activities in Antarctica or on the Moon.

\section{THE RELATIONSHIP BETWEEN INTERNATIONAL AND DOMESTIC LAW}

International law is binding at the international level, and it is no defense to breach of an international obligation that a state's domestic law differs or that the government of the state has failed to give effect to the international norm. VCLT, Arts. 27, 46. Breach of an international obligation, whether based on a treaty or customary international law, gives rise to certain automatic consequences, the first of which is an obligation to cease the breach and conform conduct to the law. See LaGrand Case (Ger. v. U.S.), 2001 ICJ (June 27), 40 ILM 1069 (2001).

On the national level, the place of international law varies from one legal system to another. In the United States, treaties are listed as part of the "supreme law of the land" in Art. VI of the Constitution. This means that they override conflicting laws, including constitutional laws, of the component states in the federal system. Asakura v. Seattle, 265 U.S. 332 (1924). The U.S. Supreme Court has long applied two important doctrines in considering the role of treaties in U.S. law. The first is that treaties are legally equivalent to a federal statute and thus the later in time will prevail in case of a conflict. The second doctrine is that whenever possible, federal statutes will be interpreted to conform to the international legal obligations of the United States. Murray v. The Schooner Charming Betsy, 6 U.S. (2 Cranch) 64, 118 (1804).

Treaties in force are not always judicially enforceable and do not always create private rights of action. A "self-executing" treaty is automatically part of domestic law and enforceable by courts, but treaties that require further legislation to implement them are non-self-executing and are therefore not justiciable until implementing legislation has been adopted. Courts look to the intent of the parties and to the language of the agreement to make the determination. See Foster v. Nielson, 27 U.S. (2 Pet.) 253, 314 (1829).

The role of customary international law in the U.S. legal system is not explicitly addressed in the Constitution. The U.S. Supreme Court determined that it is, however, part of U.S. law, declaring that "it must be ascer- 
tained and administered by the courts of justice of appropriate jurisdiction, as often as questions of right depending upon it are duly presented for their determination." The Paquete Habana, 175 U.S. 677 (1900). The exact role of customary international law and its place in the U.S. legal system are debated issues, because there are few cases on point.

Even where treaties and custom are not the primary basis for judicial decisions, they can be influential in a case. A recent example is United States v. Locke, 529 U.S. 89 (2000). A trade association of oil tanker operators, representing some 80 percent of the world's independently owned tanker fleet, brought suit seeking declaratory and injunctive relief against the state of Washington. The state had enacted regulations requiring "the best achievable protection" (BAP) from oil spill damages in the Puget Sound and imposed standards that were more stringent than those adopted by the U.S. Congress, including some governing tanker operation and design. The U.S. Supreme Court held that the state actions were preempted and that only the federal government may regulate the design, construction, and other aspects of tanker vessels. While the Court relied primarily on the Ports and Waterways Safety Act, 33 U.S.C.A. $§ 1223$ et seq., it also considered arguments that the BAP standards countered important foreign affairs interests of the federal government and cited maritime treaties to which the United States is a party. The Court agreed that the goal of national governments to develop effective international environmental and safety standards would be defeated by allowing local authorities to impose differing regulatory regimes. It noted that the scheme of regulation includes "a significant and intricate complex of international treaties and maritime agreements bearing on the licensing and operation of vessels and that this regime depends upon the principle of reciprocity." Thus, although the case rested on statutory preemption, the treaty regime lay behind the statutes and provided the context for the decision.

Those who reside in federal legal systems are familiar with the problems that arise when social issues are regulated at multiple levels of governance and among different institutions at the same level (vertical and horizontal divisions). In the best of circumstances, local, regional, and national regulation can reinforce and complement each other without duplication of effort and wasted resources. Yet, this ideal is rarely achieved, and even when there has been rational allocation of lawmaking, complex questions of jurisdiction, forum, and choice of law arise on a regular basis over matters of enforcement and dispute settlement. It should not be surprising, therefore, to see similar difficulties arise at the international level, given multiple sources of environmental regulation and the proliferation of national, regional, and global institutions.

Traditional notions of sovereignty call for reserving the maximum flexibility to national institutions to develop their own national or local policies, even while implementing and enforcing international environmental 
law. This is especially warranted under international agreements that set only broad policies and goals, and it is reflected in Principle 21 of the Stockholm Declaration on the Human Environment, which affirms the sovereign right of states to develop laws and policies concerning resource use, provided the state does not cause harm extra-territorially. Doctrines like the European "margin of appreciation" involve considerable deference to national decisionmaking subject to some international supervision. For the latter, international proceedings are crucial. Some of these are discussed in the next section. International bodies specifically concerned with the environment are described in Chapter III.

\section{E. MAKING INTERNATIONAL LAW WORK: COMPLIANCE AND ENFORCEMENT}

Ensuring compliance with international treaties and custom is one of the main issues in international law. In a society composed of sovereign states that have exclusive jurisdiction over their territory, including maritime areas and an air space, compliance with obligations that the states have accepted raises specific problems that increase when environmental matters are in question. First, most environmental problems initially arise within the limits of national jurisdiction and do not immediately and directly harm other states, so the latter cannot file claims for reparations unless the obligations are designated as ones owed erga omnes. One may think of the use of CFCs, the emission of greenhouse gases, or the destruction of biological diversity. In such instances, the normal sanction in treaty law, which consists in other states withholding equivalent treaty benefits from the breaching party, also cannot be used, and other types of noncompliance consequences must be foreseen.

Secondly, violations of MEAs are most often committed by non-state actors, from individuals to large-scale industries. Governments are responsible, because they have accepted the treaty obligations, but, in practice, compliance may be difficult, because the state must commit scarce political and economic resources to ensure the required result. In many instances, the political costs of enforcing national and international law on the private sector may be higher than when the state regulates its own activities. States have various direct sanctions available to control the behavior of state agents, from disciplinary measures to dismissal. The regulation of non-state behavior, however, is likely to require legislation that may be difficult to adopt when the non-state actors play a powerful role in the domestic political arena. This is a key factor in the environmental field. Where there are costs imposed on industries that have a high degree of political influence, the state may find it difficult to ensure compliance. Both the will and capacity of the state to comply can become compromised. 


\section{State Responsibility}

In international law, the law of state responsibility determines the consequences of a state's failure to comply with its international obligations. In general, it requires a state that breaches an international obligation to cease the violation and provide reparations for any harm caused to another state. This responsibility based on fault may be distinguished from imposition of liability for the deleterious effects of lawful acts, that is, liability without fault. In environmental law, the latter concept can be seen as an application of the polluter pays principle, requiring that the operator or actor who benefits from a lawful activity bear the risk of loss when harm is done to others. Such imposition of strict liability is rare, as detailed in Section E.

According to international law, states are responsible for international law violations that can be attributed to them. In August 2001, the International Law Commission completed its Draft Articles on the Responsibility of States for Internationally Wrongful Acts, which the UN General Assembly "took note of" in Resolution 56/83 (Dec. 2001). According to Art. 2 of the Draft Articles, a state commits an international wrong when an act or omission attributable to it constitutes a breach of an international obligation of the state. Art. 3 adds that the characterization of an act of a state as internationally wrongful is governed by international law. In other words the primary rules of conduct for states, i.e., their rights and duties, establish whether an act or omission constitutes a wrongful act. At present, as discussed in the next section, only a handful of treaties make states strictly liable for any harm that occurs in another state's territory as a result of specific activities, even if the state has otherwise complied with its legal obligations. The large majority of multilateral environmental treaties focus not on the harm to the injured state, but on the conduct of the acting state, imposing duties of comportment and of result.

Although traditional norms of state responsibility most frequently concern the treatment of aliens and their property, the Trail Smelter arbitration of 1941, recognized that principles of state responsibility are applicable in the field of transfrontier pollution, and consequently states may be held liable to private parties or other states for pollution that causes significant damage to persons or property. The UN Survey of International Law, a few years later, concluded that there is "general recognition of the rule that a State must not permit the use of its territory for purposes injurious to the interests of other States in a manner contrary to international law." UN Doc. A/CN.4/1/Rev.1 (UN Pub. 1948. V.1(1)), at 34 (1949).

The principle of state responsibility for transboundary environmental harm is contained in numerous international texts. Principle 21 of the Stockholm Declaration declares that states have the responsibility to ensure 


\section{Guide to International Environmental Law}

that activities under their jurisdiction or control do not cause damage to the environment of other states or to areas beyond national jurisdiction and refers to responsibility for transfrontier pollution in Principle 22. The rule was reiterated in Principle 2 of the 1992 Rio Declaration and was again confirmed at the 2002 World Summit on Sustainable Development. It has also been reaffirmed in declarations adopted by the United Nations, including the Charter of Economic Rights and Duties of States and the World Charter for Nature, and has been adopted by other international organizations and conferences. Its content is inserted in the Convention on the Law of the Sea (Art. 194(2)) as well as in the ASEAN Convention on the Conservation of Nature and Natural Resources, Art. 20 (Kuala Lumpur, July 9, 1985). The 1979 Geneva Convention on Long Range Transboundary Air Pollution reproduces Principle 21 stating that the Principle "expresses the common conviction that States have" on this matter. Principle 2 of the Rio Declaration appears in the preamble of the 1992 UN Framework Convention on Climate Change and Art. 3 of the Convention on Biological Diversity.

Finally, taking cognizance of these developments, the International Court of Justice recognized in an advisory opinion that " $[\mathrm{t}]$ he existence of the general obligation of states to ensure that activities within their jurisdiction and control respect the environment of other states or of areas beyond national control is now part of the corpus of international law relating to the environment." Legality of the Threat or Use of Nuclear Weapons, Advisory Opinion, 1996 ICJ 241-42, para. 29. This statement was repeated in the judgment concerning the Gabcikovo-Nagymaros Project, in which the Court also "recall[ed] that it has recently had occasion to stress . . . the great significance that it attaches to respect for the environment, not only for states but also for the whole of mankind." Case Concerning the Gabçikovo Nagymaros Project (Hung. v. Slovakia), 1997 ICJ 7, para. 53 (Sept. 25).

In order to impose an obligation to cease a harmful activity or repair harm caused, the legal basis or degree of fault on which the obligation is premised must be determined. In general, international responsibility is founded on fault imputable to the acting state. It is necessary to show that an obligation was violated and that harm resulted from the violation; it is generally not necessary to show that the acting state specifically intended the harm to result. Fault exists if the state actor fails to perform a duty or observe a standard. Generally, the applicable international rules and standards do not hold a state responsible when it has taken necessary and practicable measures, i.e., exercised due diligence.

The law of state responsibility requires establishing a link of causality between a culpable act and the damage suffered, and the damage must not be too remote or too speculative. Pollution poses specific problems for several reasons. First, the distance separating the source from the place of damage may be dozens or even hundreds of miles, creating doubts about the causal link even where polluting activities can be identified. 
Second, the noxious effects of a pollutant may not be felt until years or decades after the act. Increase in the rate of cancers as a consequence of radioactive fallout, for example, can be substantially removed in time from the polluting incident. This problem was highlighted by the 1986 Chernobyl accident, which immediately caused 29 deaths, but which directly or indirectly may have produced thousands of cases of cancer over the long term. Intervening factors may play a role as well. See Section E.2.

Third, some types of damage occur only if the pollution continues over time. This is true of the deterioration of buildings and monuments, for example, or, in certain circumstances, vegetation. Proof of causation also is made difficult by the fact that some substances cause little harm in isolation but are toxic in combination. Imputing responsibility to one source rather than another is difficult.

Fourth, the same pollutant does not always produce the same detrimental effects due to important variations in physical circumstances. Thus, dumping polluting substances in a river will not cause the same damage during times of drought as it will during periods where water levels are high. Similarly, wind or the lack of it, fog, or sunlight can modify the impact of air pollution or even the nature of pollution. Urban smog, for example, is exacerbated by atmospheric inversions (layers of warm, still air held below a cold air mass) that block elimination of the air pollutants. The latter derive from multiple sources, including industry, domestic heating, and motor vehicles. In such a situation it appears impossible to impute injury to a single precise cause in order to impose responsibility. Long-distance pollution, especially long-range air pollution, poses unique problems in identifying the author of the harm and precludes relying on traditional rules of state responsibility.

Even at a short distance, proving the identity of the polluter can pose problems. For example, gas emissions from motor vehicles are harmful, including the fumes of each individual automobile. Yet it is difficult to apply rules of responsibility and demand reparations from each driver, because the numbers are too great and the effects produced by each unit are relatively limited. Nonetheless the cumulative effects are significant due to the part played by nitrous oxide ( $\left.\mathrm{NO}_{2}\right)$ and burned hydrocarbons (HC) in the formation of ozone at medium altitudes during sunny periods; they are also factors in the depletion of forests. One answer is pollution or carbon taxes, discussed in Chapter VI, Section A.3.

Another issue of state responsibility concerns the extent to which states are accountable for the actions of private parties under their jurisdiction or control. As a general rule, it can be said that the state whose territory serves to support the activities causing environmental damage elsewhere or under whose control it occurs is responsible for the resulting harm. The necessary element of an act or omission by a state agent is generally present, because the large majority of domestic activities capable of causing serious environmental harm outside the country requires prior approval 


\section{Guide to International Environmental Law}

or licensing under domestic legislation. Such approval normally will suffice to engage the responsibility of the competent territorial authority.

The issue of reparations is also difficult. In the Chorzow Factory case, the Permanent Court of International Justice indicated the scope and purpose of reparations in the law of state responsibility:

reparation must, in so far as possible, wipe out all the consequences of the illegal act and re-establish the situation which would, in all probability, have existed, if that act had not been committed. Restitution in kind, or, if that is not possible, payment of a sum corresponding to the value which a restitution in kind would bear, the award, if need be, of damages for loss sustained which would not be covered by restitution in kind or payment in place of it.

Chorzow Factory (Indemnity) Case, 1928 P.C.I.J. (ser. A) No. 17, at 29 (Sept. 13). Various MEAs and declarations affirm that harm to the environment requires the state of origin to restore the environment to its status quo ante, and that anyone who carries out the necessary remediation is entitled to reasonable reimbursement. If it is impossible to fully restore the prior conditions, which is often the case, the parties must agree on compensation. In evaluating or measuring damages, a great deal of uncertainty exists, because the elements of the environment often are not viewed as having economic value when they remain outside the marketplace. For example, there may be wide divergence in valuing seabirds killed by an oil spill or the aesthetic value of a clean coastline. In other cases, damages may be estimated according to accepted case law from other fields, including such items as lowered property values due to pollution or lost business due to smoke or noise.

The issue of diplomatic protection arises when an individual suffers harm due to activities originating in another state. According to international law, diplomatic protection is exercised by states in order to ensure respect for international law vis-à-vis their nationals. Mavrommatis Case, 1924 P.C.I.J. (ser. A) No. 2, at 12 (Aug. 30). In such cases, typically, the injured party is physically present in the state causing the harm, and only the state of nationality may protest the wrongful act on behalf of its national. In pollution cases, then, if the victim of such pollution is unsuccessful in obtaining redress through local remedies, the national government of the injured party may (but is not required to) take up the case. If the complaint is taken, the complainant's government will present an international claim to the government on whose territory the harmful activities have taken place.

The different circumstances of injury caused by transfrontier pollution suggest that the traditional conditions for the exercise of diplomatic protection and the usual procedures to obtain reparation may not apply. In particular, it is not clear that the victim of injury must be a national of the 
state from which he claims protection. Acts of transfrontier pollution harm persons outside the boundaries of the acting state and have their effect in the victims own place of residence. Nationality is not the key element, because all who are situated on the territory or territories where the injury occurs are similarly situated and have not voluntarily subjected themselves to the jurisdiction of the state causing the injury. The claimant state can be seen as proceeding in order to protect persons within its territorial sovereignty rather than as exercising its personal competence on behalf of its citizens. Thus, an injured individual may be an alien in the state presenting the claim or even have the nationality of the accused state. In demanding reparations, the state enforces international law respecting its territory as well as in regard to its subjects.

With territory rather than nationality the usual basis for claims of state responsibility for environmental harm, diplomatic protection will maintain its traditional function only when the victims of polluting activities are found in places where the sole link between them and their state is personal: the high seas and air space above, Antarctica, outer space

Finally, it is necessary to mention the problem of abatement. One of the requirements arising from breach of a rule of international environmental law is that an activity causing significant transboundary environmental harm should cease. Where the issue is one of risk of harm, however, international law provides that lawful activities may continue, if their benefits to the state substantially outweigh the risks of transfrontier harm. In such a case, compensation still may be required if harm actually occurs through lack of due diligence. The risk-creating conduct is permitted, but the victim does not bear the burden of the injury that may result. Instead, a social responsibility is imposed upon the actor to compensate the victims for harm that occurs even though the activity is legal. Purely accidental harm, however, is a matter of the law governing strict liability and not that of state responsibility. This matter is addressed in the next section.

\section{Strict Liability}

While Stockholm Principle 21 and similar formulations can be read to impose absolute state responsibility for any transfrontier harm, whether intentional or accidental, states generally have not invoked it to assert claims for accidental harm, however damaging the impact. The Chernobyl incident is a case in point. ${ }^{1}$ Following the April 26, 1986, explosion in reactor Number 4 of the Chernobyl nuclear power plant, the resulting fire melted a portion of the uranium fuel. Although there was no nuclear

1 See L. Malone, The Chernobyl Accident: A Case Study in International Law Regulating State Responsibility for Transboundary Nuclear Pollution, 12 Colum. J. ENvTL. L. 203, 222 (1987). 


\section{Guide to International Environmental Law}

explosion and the core of the reactor did not melt, the fire that engulfed the reactor was serious and released a large quantity of radioactive material into the air.

Large amounts of fallout occurred near the plant and spread beyond. Between April 27 and May 8, nearly 50,000 persons were evacuated from towns located within a 30-kilometer radius of the plant. Two persons were immediately killed by the explosion, 29 died shortly after, and hundreds were afflicted with radiation poisoning. The foreign consequences were also severe, even though no deaths were immediately attributed to the accident. Following rapid changes in the wind direction, the radioactive cloud, which had formed, crossed the airspace of a series of countries beginning with those of Scandinavia. Four days after the incident, radiation measurements along the Swedish coast were ten times higher than normal. The radioactive cloud moved south, crossing Germany, Austria, Switzerland, Yugoslavia and Italy.

No conventional international regulation applied at the time of the accident. The Convention on Long-Range Transboundary Air Pollution (Geneva, Nov. 13, 1979) excluded pollution by radioactive elements. The USSR was not a contracting party to the Vienna Convention on Civil Liability for Nuclear Damage (May 21, 1963). Indeed, among the states that suffered effects from the radioactive cloud, only Yugoslavia had signed and ratified the Convention. There remained, therefore, only the recourse to general rules of international environmental law. After consideration, none of the affected states presented a claim to the Soviet Union.

Strict liability is foreseen in texts regulating activities considered as especially new or dangerous, such as the exploration and exploitation of the outer space, and that are largely conducted by state actors. The Convention on Principles Governing the Activities of States in the Exploration and Use of Outer Space, including the Moon and other Celestial Bodies (Jan. 27 1967), provides both for state responsibility and strict liability. First, Art. VI provides that the states parties bear international responsibility for national activities in outer space, including the moon and other celestial bodies, whether such activities are carried on by governmental agencies or by non-governmental entities. The activities of non-governmental entities in outer space, including the moon and other celestial bodies, require authorization and continuing supervision by the appropriate state, thus ensuring state involvement. Art. VII of adds that each state that launches or procures the launching of an object into space and each state from whose territory or facility an object is launched, is liable to another state or to its natural or juridical persons for harm caused by such object, or its component parts, on the earth, in air space or in outer space, including the moon and other celestial bodies. Taken together, these two provisions distinguish between responsibility based on fault for incidents in outer space (Art. VI) and strict liability for the consequences to earth of space activities (Art. VII). 
The Convention on International Liability for Damage Caused by Space Objects (Mar. 29, 1972) further develops the distinction and contains several details concerning implementation. According to its Art. II, a launching state is absolutely liable to pay compensation for damage caused by its space object on the surface of the earth or to aircraft in flight. Whenever two or more states jointly launch a space object, they are jointly and severally responsible for any damage caused. A state from whose territory or facility a space object is launched shall be regarded as a participant in a joint launching. Exoneration from strict liability is granted to the extent that a launching state establishes that the damage has resulted from another's gross negligence or from an intentional act or omission. No exoneration will be granted in cases where the damage has resulted from activities conducted by a launching state in breach of international law. Nationals of the launching state or foreign nationals participating in the launching cannot ask for compensation for damage caused by the launching state. Art. VII.

A UN General Assembly resolution proclaiming Principles Relevant to the Use of Nuclear Power Sources in Outer Space (Res. A/47/68, Feb. 23, 1993) refers to the Liability Convention in extending its scope to cover the use of nuclear power in space:

Each State which launches or procures the launching of a space object and each State from whose territory or facility a space object is launched is internationally liable for damage caused by such space objects or their component parts. This fully applies to the case of such a space object carrying a nuclear power source on board. Whenever two or more States jointly launch such an object, they shall be jointly and severally liable for any damage caused, in accordance with article $\mathrm{V}$ of the above-mentioned Convention.

Such provisions establish a regime of strict liability and not of responsibility.

Within the Antarctic system, efforts to conclude a liability annex to the 1991 Madrid Protocol partially succeeded in June 2005, with conclusion of a limited agreement on environmental emergencies, defined as any accidental event that takes place after the entry into force of the Annex, when the accident results in or imminently threatens significant and harmful impact on the Antarctic environment. The agreement, adopted as Annex VI to the Protocol on Environmental Protection, will enter into force once all the present Consultative Parties have ratified it. ${ }^{2}$

2 Article IX of the Antarctic Treaty distinguishes between Antarctic Treaty Consultative Parties, those states conducting substantial scientific activities in Antarctica, and other states parties. The former are entitled to participate in meetings that take decisions regulating conduct in the Antarctic Treaty region. 


\section{Guide to International Environmental Law}

The scope of potential liability extends to all governmental and nongovernmental activities for which advance notice is required under the Treaty, including tourism. The system is thus a "mixed" one of liability for operators whether they are governmental or non-governmental actors. This is significant, because many activities in Antarctica are conducted or sponsored by governments. Each state party is to require its operators to undertake reasonable preventive measures, establish contingency plans for responses to incidents with potential adverse environmental impacts, and take prompt and effective responsive action when an emergency results from its activities. If the operator fails to take responsive action, the relevant party is "encouraged" to take such action, as are other parties after notifying the party of the operator, if such notification is feasible. Any operator that fails to take prompt and effective responsive action is liable to pay the costs of responsive action taken by other parties. Where the defaulting operator is a state operator and no party took responsive action, the state operator is liable to pay the equivalent of the costs of responsive action that should have been taken. This sum is paid into a fund maintained and administered by the Secretariat of the Treaty for the reimbursement of the reasonable and justified costs incurred by a party or parties in taking responsive actions to environmental emergencies Art. 12.

Liability is strict with some exceptions; liability will not be imposed if the operator proves that the emergency was caused by (1) an act or omission necessary to protect human life or safety; (2) an exceptional natural disaster that could not have been reasonably foreseen, provided all reasonable preventive measures have been taken; (3) an act of terrorism; or (4) an act of belligerency against the activities of the operator. Sovereign immunity for warships is maintained, limits on liability are provided, and operators are to be required by each party to maintain adequate insurance or other financial security.

Residual state liability is also included in the Annex. Although Art. 10 is drafted in the negative, to assume no liability, it nonetheless sets forth circumstances in which a party will be held liable:

A Party shall not be liable for the failure of an operator, other than its State operators, to take response action to the extent that the Party took appropriate measures within its competence, including the adoption of laws and regulations, administrative actions and enforcement measures, to ensure compliance with this Annex.

Although this article clearly envisages state liability for state operators, it discusses state responsibility as well. It refers to a state's failure to comply with its legal obligations to take appropriate measures to prevent harm by non-state actors within its jurisdiction. Such omissions are often the basis of claims against states under the law of state responsibility. 
Since 1978, the International Law Commission has considered the question of "international liability for injurious consequences arising out of acts not prohibited by international law." In 1997, the ILC decided to deal only with the question of prevention of transboundary damage from hazardous activities, and within four years it was able to present to the UN General Assembly a completed set of 19 articles on this topic. See Draft Articles on Prevention of Transboundary Harm from Hazardous Activities, in Report of the International Law Commission on the Work of its Fifty-Third Session, UNGAOR, 56th Sess. Supp. No. 10, UN Doc. A/56/10 370 (2001). The General Assembly reviewed the articles and, pressed by certain member states, asked the ILC to continue working on the topic of international liability, "bearing in mind the interrelationship between prevention and liability." Res. 56/82 of Jan. 18, 2002. In July 2004 the ILC provisionally adopted a draft set of Principles on Allocation of Loss in the Case of Transboundary Harm Arising Out of Hazardous Activities on first reading. After comments by states, the text was finally adopted in May 2006. See Draft Report of the International Law Commission on the Work of its Fifty-Eighth Session, Chapter V: International Liability for Injurious Consequences Arising out of Acts not Prohibited by International Law (International Liability in Case of Loss from Transboundary Harm Arising out of Hazardous Activities), UN Doc. A/CN.4/L.693/Add.1, June 9, 2006. To a large extent, these efforts can be seen to supplement and complete the ILC Articles on Responsibility of States for Internationally Wrongful Conduct, although the content of the adopted rules appears largely to repudiate state liability when the state has complied with the Draft Articles on Prevention.

The draft principles correctly approach the issue as one of allocating the risk of loss due to harm resulting from lawful economic or other activities, when the relevant state has complied with its due diligence obligations to prevent transboundary harm. The articles provide a general framework for states to adopt domestic law or conclude international agreements to ensure prompt and adequate compensation for the victims of transboundary damage caused by lawful hazardous activities. An additional purpose of the draft principles is mentioned: "to preserve and protect the environment in the event of transboundary damage, especially with respect to mitigation of damage to the environment and its restoration and reinstatement." This progressive principle should be read in the light of the broad definitions of damage,,$^{3}$ environment ${ }^{4}$ and hazardous

3 In addition to personal and property losses, damage includes "loss or damage by impairment of the environment, the costs of reasonable measures of reinstatement of the environment, including natural resources, and the costs of reasonable response measures." Principle 2(1) (iii-v).

4 Environment includes natural resources, both abiotic and biotic, such as air, water, soil, fauna, and flora, and the interaction between the same factors, and the characteristic aspects of the landscape. Principle 2(b). 


\section{Guide to International Environmental Law}

activity $^{5}$ set forth in Principle 2. While there is an important restriction in the exclusion of harm to the commons from the scope of these principles, on the whole they give a prominent place to the protection and preservation of the environment per se for the benefit of present and future generations.

The draft principles support existing state practice, which largely channels liability to the owner or operator and requires financial guarantees to cover future claims of compensation. In appropriate cases, industry-wide funds should be established at the national level. The articles do not support strict liability between states, unless the state itself is the operator. The Commentary to the Draft Principles is clear that "[i]t is envisaged that a State could be an operator for purposes of the present definition" and thereby become strictly liable. UN Doc. A/CN.4/L.693/Add.1, at 41, para. 33. For non-state activities, state obligations are more limited. Principle $4(5)$ provides that in the event that the measures for operator liability are insufficient, "the State of origin should also ensure that additional financial resources are made available." The state also must promptly notify all states that are potentially or actually affected by an incident, ensure that appropriate response measures are taken, and provide domestic remedies against the responsible party. Other measures are recommended, including consultation on measures of mitigation, seeking the assistance of competent international organizations, and providing appropriate access to information on remedies. In addition, states may negotiate specific agreements on the topic of strict liability.

The lack of any serious consideration of state liability may be understood in the context of the prior articles on prevention: failure to fulfill the due diligence duty to prevent breaches an international obligation and shifts the applicable legal regime to one of state responsibility. Still, to dismiss liability as "a case of misplaced priority" 6 ignores existing positive law, which has accepted the principle of state liability in a series of treaties concerning ultrahazardous activities that are largely conducted by state actors. Nonetheless, the ILC appears to have decided that strict liability of states does not even have support as a measure to progressively develop the law. Instead, the ILC limits itself to noting that certain categories of hazardous activities might be included in treaties providing for state-funded compensation schemes to supplement civil liability. It stops well short of finding that such compensation is legally required.

5 In probably the broadest definition contained in the draft articles, a hazardous activity "means an activity which involves a risk of causing significant harm." Principle 2(c). This definition appears to extend strict liability considerably beyond that provided in most domestic law.

6 P.S. Rao, "First Report on the Legal Regime for Allocation of Loss in Case of Transboundary Harm Arising out of Hazardous Activities," UN Doc. A/CN.4/531 7 (2003). 
Strict liability of states thus remains controversial, and the preference is clearly in favor of imposing civil liability on operators. Those subject matters for which state liability has been accepted in practice are consistent with this approach, because they largely concern activities undertaken by government actors, at least until recently: e.g., outer space exploration and exploitation and Antarctic scientific research. States seem willing to accept strict liability for their own conduct, but not for that of private actors. 